\title{
Effect of Climate Change on Agricultural Output Growth in Ethiopia: Co-Integration and Vector Error Correction Model Analysis
}

\author{
Melaku Adinew ${ }^{1}$, Gebrekirstos Gebresilasie ${ }^{1}$ \\ ${ }^{1}$ Department of Economics, Dire Dawa University, Ethiopia
}

\begin{abstract}
This study examined the effect of climate change on agricultural output growth in Ethiopia. Co- Integration and Vector Error Correction Model estimation technique and data for the period 1981-2016 was used. Changing in annual mean temperature, annual mean rainfall, carbon dioxide emission and forest depletion were used to attribute variables for climate change. The result of vector error correction model indicate that both in the long-run and short-run, carbon dioxide emissions negatively affect agricultural output growth in Ethiopia. Annual temperature and annual rainfall negatively affect agricultural output growth in the long run and short run respectively. On the other hand, forest depletion has positive effect on agricultural output growth both long run and the short-run respectively. Policy maker should develop policies to reduce sources of carbon dioxide emissions and introduce mitigation and adaptation measures to sustain the agricultural economic growth.
\end{abstract}

Keywords: agricultural output growth; climate change; VECM; Ethiopia

\section{Introduction}

Ethiopia is the second largest country in terms of its population and the fifth largest economy in sub-Saharan Africa (SSA) and it has experienced to record a strong economic growth in recent years [1]. As a result this country brought a significant structural change and economic reforms. However, it is still among the lowest income countries [2]. In the last decade annual average GDP growth rate was about ten percent through motivated public investments in agriculture and infrastructure. The proportion of households living below the poverty line of US\$1.9 purchasing power parity (PPP), was decline from 29.6 percent in 2013 to 27.2 percent in 2015 and its estimated decline to 24.6 percent in 2018 [3].

The agriculture sector is the backbone of Ethiopia's economy and livelihoods. It is the leading sector in terms of contribution to the country's economy for other sectors. However, the share of agriculture in the GDP declined over last decade from 47\% in 2004/05 to 39\% in $2014 / 15$. It is contributes $73 \%$ of employment, and supplies $70 \%$ of the raw-material requirements of local industries [4] and $90 \%$ of exports [5,6]. The sector is dominated by over 15 million smallholders producing about 95 percent of the national agricultural production [6]. This shows that the overall economy of the country and the food security of the majority of the population depend on small holder agriculture. Yet, it is still highly depends on traditional farming methods and a rain-fed farming system, and it is vulnerable to environmental and climate-related shocks [7].

Agricultural production in Ethiopia is highly sensitive to climate change. Increasing frequency and intensity of temperatures extremes; decreasing in the amounts and distribution of precipitation; and water availability are a few examples of climate-related challenges to Ethiopia's agriculture sector [8]. The economy has been facing fluctuations in the crop production over the years. The major fluctuations caused by variability of rains during the production season [9]. Grain crops are the major share of agricultural production in Ethiopia, such as, cereals, pluses and oilseeds are most important grain crops in terms of area cultivation, yield and consumption. Cereals accounts about $87 \%$ of total grain production, followed by 
pluses (14\%), and oilseeds (3\%). At country level, grain crops constitute the majority of the annual total agricultural crop production. For the private small holder farmers more than half of $(62 \%)$ the share of total agricultural crop output was accounted by grain crops during the 2017/18 production year [34].

The evidence of the global climate changing and projections showed that the rate of change will increase in the future. Global temperatures are expected to increase by $1.1-2.6^{\circ} \mathrm{C}$ by the end of the $21^{\text {ts }}$ century. Africa is the most vulnerable continents in climate change which is more than the world average. The mean annual temperature is expected to increase by 2.0 $3.7^{\circ} \mathrm{C}$ and at the result of this about $350-600$ million Africans will be at vulnerability from increased water stress by the 2050s [10]. Ethiopia will warming in all seasons of between $0.7^{\circ} \mathrm{C}$ and $2.3^{\circ} \mathrm{C}$ by the $2020 \mathrm{~s}$ and between $1.4^{\circ} \mathrm{C}$ and $2.9^{\circ} \mathrm{C}$ by the $2050 \mathrm{~s}$ and also a very small change in average rainfall of $0.4 \%$ by the 2020s and $1 \%$ by the 2050s [11]. Between 1960 and 2006 the mean annual temperature has been increased by $1.3^{\circ} \mathrm{C}$, and on average rate of $0.28^{\circ} \mathrm{C}$ per decade [12]. But the rainfall is uncertain given the historical variability, but suggests a larger percentage of precipitation falling during heavy events [13]. The level of $\mathrm{CO}_{2}$ concentration is projected to increase the global mean temperatures by $3^{\circ} \mathrm{C}$ by 2050 [14]. Green House Gas (GHG) emissions would be more than double from $150 \mathrm{Mt} \mathrm{CO} 2$ emissions today to $400 \mathrm{Mt} \mathrm{CO} 2$ emissions in 2030 in Ethiopia. Agricultural and forestry are the main sources of GHG emissions. This accounts more than $85 \%$ of GHG emissions [12].

Many studies based on projection concluded that the agriculture sector mostly affected by climate change. According to [8], Climate change vulnerability and climate shocks negatively influence agricultural production. Rise in temperatures reduced soil moisture availability, water availability and quality and changes to timing and distribution of agricultural pests and diseases. Change in rainfall patterns resulting in crop productivity decline and failure of yields. The negative impacts of climate change are basically influence the contribution agricultural outputs for GDP [15] and increasing temperature and decreasing precipitation are both damaging the agricultural economic activities of Ethiopian [16].

According to [17] were used a Ricardian model, the projected result of current and future agricultural production as a function of temperature and precipitation over a 50 year period decline in agricultural productivity and this projection of climate change accounted for 30 percent less average income when compared with the absence of climate change. [18] were reported using the probit estimation in Nile Basin, the estimates of climatic variables Belg and Mehere rainfall levels and temperature level have negative and statistically significant on agricultural production. [19] Was used a Panel data estimation, found that temperature and rainfall influenced agricultural cereal crop productivity negatively. [20] Were also reported the OLS regression result showed that variability in rainfall has a significant and negative effect during the cropping season.

Although, some empirical studies have examined the potential impacts of climate change on agricultural output growth based on projection [11, 17, 21, and 22]. However, there is no new sufficient research evidence of the effect of climate changes on the agricultural production growth using time series analysis $[19,23]$. The existing studies have so far not been able to identify a causal relationship on how climate change will affect consequently agricultural production growth. Therefore, the main objective of this study was concerned with empirically assessing the effect of climate change on agricultural output growth in Ethiopian for last continuous years. 


\section{Materials and Methods}

\subsection{Source and type of data}

The study totally relies on secondary sources and the time series data collected from the various include published and unpublished sources such as annual and quarterly reports of Central Statistics Agency (CSA) and World Bank (WB) for the period 1981-2016 are used.

\subsection{Pre-estimation and post estimation Tests}

The classical methods of estimation are based on a set of assumptions one of which the variable should be stationary. A variable is said to be covariance stationary if the mean and the variances of the variable are constant over time and the covariance between two periods only on the gap between the periods, and not the actual time whereas a non-stationary series has a different mean at different points in time and its variance increases with time. If a nonstationary time series is regressed on one or more non-stationary time series variables, the results are prone to spurious regression problems [24]. Thus, testing the stationary of the variable and correcting if it is not is the first task before estimating the result.

\subsubsection{Unit-Root}

Unit root is special case of random walk model, which is one class of non-stationary series. To detect the problem of unit root, the Augmented Dickey Fuller test is employed. While testing for stationary, if a variable becomes stationary at level, then it is said to be integrated of order zero, I (0). And if the variable is stationary at its first difference it is said to be integrated of order one I (1). Similarly, if a variable can be transformed to stationary series by differencing $n$ times, then it is integrated of order $n, I$ (n) [25].

$$
\Delta Y_{t}=\beta_{1}+\beta_{2} t+\delta Y_{t-1}+\alpha_{i} \sum_{i=1}^{n} \Delta Y_{t-i}+u_{t}
$$

In equation (1) $t$ is time period, $U_{t}$ is a pure white noise error term and

$\Delta \mathrm{Y}_{\mathrm{t}-1}=\left(\mathrm{Y}_{\mathrm{t}-1}-\mathrm{Y}_{\mathrm{t}-2}\right) ; \Delta \mathrm{Y}_{\mathrm{t}-2}=\left(\mathrm{Y}_{\mathrm{t}-2}-\mathrm{Y}_{\mathrm{t}-3}\right)$ etc [24].

\subsubsection{Model specification}

Most of macroeconomics time series data are exposed to the problem of non-stationary in the process of econometric analysis. The data may lead to time variant as mean and variance and violated the basic assumption of OLS. Therefore, it is important to test the variables using the co-integrated and error correction model to solve the problems encountered with problem of OLS regression and also to check the long-run and short-run relationship \& impacts of the variables to be estimated. Mean and variance are constant over time and the value of covariance between the two-time periods depends on distance or lag. When the mean, variance, and auto covariance of individual time series are not time invariant, these time series data are not stationary $[4,26]$.

The Co-integration procedure is applied if a time series is non-stationary at their level. To find the long run relationship among the variables, in this study, co integration and vector error-correction model are used. If two $I(1)$ series $x$ and $y$ are co-integrated, then there is exist unique $\alpha_{0}$ and $\alpha_{1}$ such that $u_{t} \equiv y_{t}-\alpha_{0}-\alpha_{1} x_{t}$ is $I(0)$. In the single-equation model of co- 
integration where $y$ as the dependent variable and $x$ as set of explanatory variables, in this case the error-correction model can be written as

$$
\Delta y=\beta_{0}+\beta_{1} \Delta x_{t}+\lambda u_{t-1}=\beta_{0}+\beta_{1} \Delta x_{t}+\lambda\left(y_{t-1}-\alpha_{0}-\alpha_{1} x_{t-1}\right)+\varepsilon_{t}
$$

Where the constant is only present in the long-run relationship [4]

If AgrGDP growth (LAgrGDP) has a long-run relationship with climate change variables, such as mean annual temperature (Tem), mean annual rainfall (Pre), Carbon dioxide $\left(\mathrm{Co}_{2}\right)$ and forest depilation (For), the additional step is to investigate the causal relationship among these variables because two or more variables are co-integrated.

Therefore, the VECM model is as follows

$$
\begin{aligned}
& \Delta L A g r G D P_{t}=\gamma\left(\text { LAgrGDP }_{t-1}-\alpha_{0}-\alpha_{1} \text { LTem }_{t-1}-\alpha_{2} L \operatorname{Pr} e_{t-1}-\alpha_{3} \text { LCo }_{t-1}-\alpha_{4} \text { LFor }_{t-1}\right)+ \\
& \sum \beta_{11(i)} \Delta L A g r G D P_{t-i}+\sum \beta_{12(i)} \Delta \operatorname{Tem}_{t-i}+\sum \beta_{12(i)} \Delta \operatorname{Pr} e_{t-i}+ \\
& \sum \beta_{12(i)} \Delta C o 2_{t-i}+\sum \beta_{12(i)} \Delta F o r_{t-i}+\varepsilon_{t}
\end{aligned}
$$

The signs the above the variables suggest the anticipated relationship between each explanatory variable with the dependent variable $\left(\operatorname{AgrGDP}_{\mathrm{t}}\right)$. The Gross domestic production from agricultural product of a country is affected by numerous factors. But in this study assumed that some of others basic factors are constant.

\subsubsection{Description and excepted sign of the variables The dependent variable}

AgrGDP $_{\text {t: }}$ - Gross domestic production from agricultural economic activities, such as agriculture, forestry, and fishing, value added (\% of GDP). Agriculture sector in terms of contribution to the country's overall economy employment, supplies of the raw-material requirements of local industries and exports for foreign exchange.

\section{The independent variables}

Tot:-Mean annual temperature in degree Celsius per year, the historical observed data of global temperatures were increased by the end of the $21^{\text {ts }}$ century. Mean annual temperature has been increased over a year. The rising in temperatures reduced soil moisture, water availability and quality and changes to timing and distribution of agricultural pests and diseases. Mean annual temperature has been a negative relationship between agricultural economic growths $[8,18$, and 19]. Therefore, the expected sigh of mean annual temperature is negative.

Prêt:-Precipitation is the mean annual rainfall (millimeters per year). The Change of rainfall patterns that resulting decline in crop productivity and failure of yields. The amount of rainfall increasing or decreasing from normal condition has negative influence on arable land preparation, pre and post-harvesting of production [15, 18-20, 23]. Therefore, the expected sigh of mean annual rainfall is negative.

Co2t:-Carbon dioxide damage (\% of GNI). Emission of $\mathrm{Co}_{2}$ from different elements increases in global warming. The root of global warming problem is found in worldwide changes in fossil fuel consumption. Gases, primarily carbon dioxide concentration rises unnecessarily, it more 
heat within the atmosphere and causing rising in worldwide temperatures. Global warming is a great negative relationship for agricultural production [10,27]. Therefore, the expected sigh of Carbon dioxide damage is negative

Fort:-Net forest depletion (\% of GNI). Forested land has two significant purposes, one is sources of agricultural arable land and the other is for fixation of carbon dioxide emission and cools down of global warming. For instance, between 2000 and 2008 agricultural land is expanded by about 4 million hectares in Ethiopia. This new agricultural land came from conversion of forestlands, woodlands, and shrub lands and also the country's demand for agricultural land expected to increase from 15 million ha in 2008 to 34 million ha by 2030 [28]. Area under grain crops (cereals, pulses, oilseeds) increased over the past decades from 10 million hectares in 2005/2006 to 12.4 million hectares in 2014/2015 [6]. Therefore, the expected sigh of forest depletion is positive with agricultural production growth.

\section{Result and Discussion}

This section is to analyze the data collected for the purpose of determining the effect of climate change on agricultural production growth contribution for gross domestic production of Ethiopian economy. Climate change attributed variables in long period rainfall patterns, temperature and carbon dioxide. To this effect, the times series properties of the data employed in the study were examined. Thereafter, the analysis of the effect of climate change on agricultural output growth Error Correction Model was conducted. Before running the Error Correction Model, pre-estimation test was conducted. These are unit root test and cointegration tests. The unit root test was applied to determine the stationarity of each variables and Co-integration test to determine the existence of long-run relationships among variables.

\subsection{Unit root test results}

Unit root test is very important to determine the order of integration of the variables and to avoid the occurrence of spurious regression. Accordingly, the Augmented Dickey Fuller (ADF) test was applied to find the existence of unit-root in each of the time series. The null hypothesis in ADF tests is the data series are non-stationary (unit root) against the alternative hypothesis of the stationary process. The ADF result of both with and without trend show in the table 3.1. In the level and the first differences the variables are stationary. Therefore, the results Augmented Dickey Fuller unit-root tests indicate that mean annual temperature and mean annual rainfall variables are found to be stationary at level I (0), where as the remaining variables are stationary at first difference, $\mathrm{I}(1)$. Note that the series is statistically significant and null hypothesis of non-stationary can be rejecting when ADF test statistics value is greater than the critical value.

Table 3.1. Unit Root Test Result

\begin{tabular}{|l|l|c|l|c|c|c|}
\hline \multirow{2}{*}{} & & \multicolumn{2}{|c|}{ Level I(0) } & \multicolumn{2}{c|}{ First Difference I(1) } & $\begin{array}{c}\text { Order of } \\
\text { Integration }\end{array}$ \\
\cline { 3 - 7 } & & ADF & P-Value & ADF & P-Value & \\
\hline \multirow{2}{*}{$\ln$ AgrGDP } & Intercept & -0.844 & 0.8059 & -4.898 & 0.000 & \multirow{2}{*}{ I(1) } \\
\cline { 2 - 6 } & Trend + Intercept & -1.992 & 0.6056 & -4.877 & 0.003 & \\
\hline LnTem & Intercept & -2.637 & 0.0857 & -7.247 & 0.000 & \\
\hline
\end{tabular}




\begin{tabular}{|c|c|c|c|c|c|c|}
\hline & Trend +Intercept & -4.650 & 0.0008 & -7.143 & 0.000 & $\mathrm{I}(0)$ \\
\hline \multirow[t]{2}{*}{ LnPre } & Intercept & -4.930 & 0.000 & -9.195 & 0.000 & \multirow[b]{2}{*}{$\mathrm{I}(0)$} \\
\hline & Trend +Intercept & -5.632 & 0.000 & -9.099 & 0.000 & \\
\hline \multirow[t]{2}{*}{ LnFore } & Intercept & -1.726 & 0.4175 & -6.997 & 0.000 & \multirow[b]{2}{*}{$\mathrm{I}(1)$} \\
\hline & Trend + Intercept & -1.509 & 0.8262 & -6.927 & 0.000 & \\
\hline \multirow[t]{2}{*}{$\operatorname{lnCo} 2$} & Intercept & -1.653 & 0.4555 & -4.817 & 0.001 & \multirow[b]{2}{*}{$\mathrm{I}(1)$} \\
\hline & Trend + Intercept & -0.486 & 0.9840 & -5.483 & 0.000 & \\
\hline
\end{tabular}

Note: - I (0) and I (1) denote stationary at level and first difference, respectively.

Table 3.2. Testing the residual for unit root

\begin{tabular}{llccc}
\hline Variable & $\begin{array}{l}\text { Augmented } \\
\text { Dickey- Fuller } \\
\text { Test Statistic }\end{array}$ & $1 \%$ Critical value & $5 \%$ Critical value & Probability value \\
Residual & -4.203 & -3.682 & -2.972 & 0.0007 \\
\hline
\end{tabular}

The residual is stationary at $1 \%$ level of significance

\subsection{Co-integration test}

Co-integration test is conduct to identify the existence of long run relationship among variables included in the model. For this study, the Johansen test for co-integration was applied. Since all variables stationary, i.e. were found stationary at level and fist difference. The Johansen tests assume that the null hypothesis of no long run relationship between the dependent and independent variables is tested against the alternative hypothesis. Then the null hypothesis is not accepted and it can be concluded that there exist a long run relationship among the considered variables.

Table 3.3. Johansen tests for co integration

\begin{tabular}{|l|l|l|l|l|l|}
\hline $\begin{array}{l}\text { Hypothesis } \\
\text { Rank }\end{array}$ & $\begin{array}{l}\text { Trace } \\
\text { statistic }\end{array}$ & $\begin{array}{l}5 \% \text { critical } \\
\text { value }\end{array}$ & $\begin{array}{l}\text { Maximum } \\
\text { Rank }\end{array}$ & $\begin{array}{l}\text { Max-Eigen } \\
\text { statistic }\end{array}$ & $\begin{array}{l}5 \% \text { critical } \\
\text { value }\end{array}$ \\
\hline None & $87.0964 *$ & 68.52 & None & $42.9332 *$ & 33.46 \\
\hline At most 1 & 44.1632 & 47.21 & At most 1 & 19.3120 & 27.07 \\
\hline At most 2 & 24.8512 & 29.68 & At most 2 & 16.9120 & 20.97 \\
\hline At most 3 & 5.4837 & 15.41 & At most 3 & 5.4837 & 14.07 \\
\hline At most 4 & 2.4555 & 3.76 & At most 4 & 2.4555 & 3.76 \\
\hline
\end{tabular}

Note: * indicates that the Trace statistic or the Max-Eigen statistic is greater than the 5\% critical value

According to table 3.3, Johansen tests for co-integration showed that the first rank indicated, trace statistic is greater than critical value, there is no co-integration among the variables and reject the null hypothesis and accept the alternative hypothesis. In the second rank trace statistic is less than critical value, there is co-integration among the variables and accept the null hypothesis. This means, there is one co-integration in Johansen tests among the variables. Therefore, now conclude that all variable included in the model were co-integrated and they have long-run association ship among the variables and moving together in the longrun. The variables were co-integrated; the next step is to run the vector error-correction model to identify the short-run and long-run relationship among the variables. 


\subsection{Error correction model}

As Johansen co-integration test result showed that, there exists of the long-run relationship among variables. The error correction representation of the VAR model is estimated as a next step after estimation of the long-run coefficients. The VECM showed that the long-run and short-run relationship between climate change variables and agricultural economic growth in Ethiopia.

As reported in table 3.4, the error correction coefficient $\left(\mathrm{ECT}_{\mathrm{t}-1}\right)$ is negative sign and statistically significant at $1 \%$ significant level. The coefficient of error correction show that how rapidly a variable adjustment to equilibrium and it should be negative and significant. A highly significant error correction term is an additional confirmation of the existence of a stable long-run association. The error correction coefficient suggests that the speed of adjustment of any short-run disequilibrium towards the long-run equilibrium is $12.76 \%$ each year.

Table 3.4. ECM estimation results (dependent variable=D[AgrGDP]) Long-Run Estimation Short-Run Estimation

\begin{tabular}{|c|c|c|c|c|c|}
\hline Variables & Coefficient & P-Value & Variables & Coefficient & P-Value \\
\hline In temperature & -4.271 & $0.000 * *$ & $\operatorname{ECT}(t-1)$ & -1.276 & $0.000 * *$ \\
\hline ln precipitation & 0.141 & 0.878 & $\Delta \ln$ temperature & 2.138 & 0.220 \\
\hline ln forest depletion & 0.129 & $0.009 * *$ & $\Delta \ln$ precipitation & -0.478 & $0.002 * *$ \\
\hline \multirow[t]{3}{*}{$\ln \mathrm{CO}_{2}$} & -0.153 & $0.000 * *$ & $\Delta \ln$ forest depletion & 0.182 & $0.001 * *$ \\
\hline & & & $\Delta \operatorname{lnco} 2$ & -0.254 & $0.022 *$ \\
\hline & & & Con & 0.0008 & 0.941 \\
\hline \multicolumn{3}{|c|}{ Akaike's information criterion } & \multicolumn{3}{|l|}{-12.6123} \\
\hline \multicolumn{3}{|c|}{ Hannan and Quinn information criterion } & \multicolumn{3}{|l|}{-11.2611} \\
\hline \multicolumn{3}{|c|}{ Schwarz's Bayesian information criterion } & \multicolumn{3}{|l|}{-8.53575} \\
\hline
\end{tabular}

Note: ** and * denote significance at 1\%, and 5\% levels; respectively. ECM is residual from long run model estimation.

The tables 3.4 showed that mean annual temperature has strongly significant negative relationship with agricultural economic growth in the long-run. This means as $1 \%$ increase in mean annual temperature would be leads to decrease in agricultural economic growth by $4.27 \%$ in the long-run. The same to mean annual temperature, carbon dioxide emission also has negative relationship with agricultural economic growth and it is strongly significant at $1 \%$ level in the long-run and 5\% level in the short run. As 1\% increase in carbon dioxide damage that causes agricultural economic growth decline by $0.153 \%$ in the lung-run and $0.254 \%$ in the short-run. The mean annual rainfall has negative relationship in the short run on agricultural production and strongly significant at $1 \%$ level. This means $1 \%$ change in the rainfall that causes to decline the agricultural production by $0.478 \%$ in the short run

Forest depletion result showed that a positive influence on agricultural economic growth in long-run and short-run and was significant at $1 \%$ significant level. The result implies that forest land has two effects for agricultural economic growth. Forest laded used to source of arable land, as increase arable land that leads to increase the agricultural production. On the other hand, forest land used for observation of carbon dioxide emission, decline the global 
temperature warming and increase arable land soil precipitation. This leads to increase the agricultural production. Therefore, the result showed that $1 \%$ forest depletion leads to increase of agricultural production by $0.129 \%$ in the long run and $0.18 \%$ in the short run.

In order to perceive the trend of temperature has used average temperature data. The results showed that average annual temperature was an increased by $1.690 \mathrm{C}$ for the last three decades. The average decade raised was by $0.640 \mathrm{C}$. This showed that a continuous increases in temperature across the country. Average annual temperatures have been increasing to continue leading to climate change and caused to decline in GDP of agriculture. Therefore, the trend of climate change variable temperature showed that a negative effects on agricultural economic growth.

The effect of climate change have seen that, the daily temperature is very hoot; the soil moisture and vegetation covers has been declined, water availability in the ground, lakes and rivers have been shriveled; changes the timing and distribution of agricultural pests and diseases have been increased. This is in line with the results reported by several projection studies $[8,10,29-31]$. The same thing to that the average of rainfall trends was vary over the year. It found the lost in 1984/5 and 2002/3, which was the disastrous droughts occurred in the country. The rainy period might be shorter with higher intensity which directly or indirectly affects agricultural products, as also supported by pervious projected study's results [2, 23]. The evidence of carbon oxide emission showed that an increasing for the last three decades. This indicates that to increase the concentration of $\mathrm{CO}_{2}$ emissions in atmosphere. The concentration of $\mathrm{CO}_{2}$ results from farming activities, such as usage of fertilizer and the conversion of forested areas agricultural land. These results are in line with some earlier studies $[12,10$, and 27].

\subsection{Diagnostic tests and model fitness}

The estimated model has a good fit can be seen from R-squared and adjusted R-squared and the F-statistics of the model. R-squared measures goodness of fit statistics of the model containing the explanatory variables. It desirable to the measures how the regression model has a correlation coefficient between the values of the dependent variable and the corresponding fitted values. The value of F-statistics indicates that the explanatory variables of the model are jointly statistically significant to explaining of growth of agricultural production.

Diagnostic tests employed to check the problem of serial correlation, misspecification and non-normality of the variables in the model. The Lagrange multiplier (LM) test to check problem of serial correlation of the residual, Jarque-Bera test to check the normal distribution of error term and Ramsey RESET Test if the model is specified correctly or not. This implies that the null hypothesis of autocorrelation, normality no omitted variable bias fail to reject in each diagnostic test. Therefore, applied of the VECM was free from autocorrelation, normality and misspecification problem

Table 3.5. Diagnostic Tests and Model Fitness

\begin{tabular}{ll}
\hline Diagnostic Checks & \\
\hline R-squared & 0.7422 \\
Adjusted R-squared & 0.7089 \\
F- Statistics & 22.31 \\
Prob (F- statistics) & 0.000
\end{tabular}


Note: P-value of all tests is greater than $5 \%$ significant level

\subsection{Granger causality test}

Granger causality test provides that important information of the causal direction between the variables. In this study, Granger causality Wald tests was employed to determine the causal linkages between the main climate changing attributed variables (i.e. CO2 and temperature) and agricultural output growth in Ethiopia. The null hypothesis of the causality test is does not granger causality between climate change variables and agricultural output growth.

Table 3.6. Granger causality Wald tests

\begin{tabular}{llll}
\hline Equation & Excluded & chi2 & P-value \\
\hline $\ln G D P$ & In Temperature & 8.1168 & 0.017 \\
ln Temperature & $\ln G D P$ & 8.8046 & 0.012 \\
$\ln G D P$ & $\ln C \mathrm{O}_{2}$ & 12.527 & 0.002 \\
$\ln \mathrm{CO}_{2}$ & $\ln G D P$ & 7.7862 & 0.02 \\
\hline
\end{tabular}

Note: P-value of all tests is less than 5\% significant level

The interest of here to analysis the existence of casual relationship between and also determines a bi-directional (two ways) granger causality between the variables. The result of the test in Table 3.6, the null hypothesis does not Granger causality is rejected in this case, which means all the p-values are less than 5\% significant level. A granger causality test result indicated that, climate changing variables (i.e. $\mathrm{CO}_{2}$ and temperature) granger causes agricultural output growth in Ethiopia and agricultural activities granger cause climate changing variables (i.e. $\mathrm{CO}_{2}$ and temperature) at less than $5 \%$ significant level. This implies that the lagged values of climate changing variables have a significant predictive power when added to equation of agricultural output growth and past value of agricultural activities also have significant linear predictive power on current value of climate changing variables.

\section{Conclusion}

This study examined the effect of climate change on agricultural economic growth in Ethiopia. The study used Co-integration and Vector Error Correction Model estimation technique for the data from the period 1981-2016. Changes in annual temperature, annual rainfall, carbon emission and forest depletion were used to capture climate change. The results of vector error correction model indicate that both in the long-run and short-run, carbon dioxide emissions negatively affect agricultural output growth in Ethiopia. Annual temperature and annual rainfall adversely affect agricultural output growth in Ethiopia in the long run and short run respectively. In addition, forest depletion impacts positive on agricultural output growth in Ethiopia in long run and the short-run. 
These results imply that Ethiopian government and stakeholders should develop forced policies to reduce sources carbon dioxide emissions. The intervention that required to reducing sources carbon emissions, such as consumption fossil fuels, gas flaring, bush burning, burning of residential byproducts, fuel used machines, deforestation. The policymakers and government should implement policies that to promote the use of environmental-friendly machines and technologies that generate smallest greenhouse gases, such as people are encouraging to adopt agro-forestry, use of improved bio-fuels, energy saving machines, climate smart agricultural technologies, like mitigation role such as green house gas emission minimization and adaptation role such as improvement of soil water storage capacity and minimizing soil erosion, farmers will be adopt increasing productivity inputs with in fixed cultivated land rather than expansion of new forest cultivated land.

\section{References}

[1] African Development Bank Group (ADBG), (2010). Ethiopia's Economic growth Performance: Current Situation and Challenges: Economic Brief: Volume1, Issue 5

[2] International Monetary Fund (IMF), (2018). The Federal Democratic Republic Of Ethiopia, IMF Country Report No. 18/18. International Monetary Fund $70019^{\text {th }}$ Street, NW Washington, D. C. 20431 USA

[3] World Bank, (2016). The $5^{\text {th }}$ Ethiopia Economic Update Country Report, Why So Idle? Wages and Employment in a Crowded Labor Market

[4] Wondifraw Z., James W. and Haile K. (2016). African Economic Outlook www.africaleconomicoutluk.org

[5] Wondwossen B. and Seyoum T.,(2014). The Economic Contribution of Copyright Industries in Ethiopia. World Intellectual Property Organization.

[6] Central Statistics Agency (CSA), (2016). Agricultural Sample Surveys 2015/2016 (2008 E.C.), Volumes I-IV. Federal Democratic Republic of Ethiopia; Ethiopia Central Statistics Agency (CSA), Addis Ababa.

[7] Adefris T., Girma M. and Habtamu A., (2013). Impacts of climate change on crop production in Ethiopia. Ethiopian Institute of Agricultural Research, Addis Ababa, Ethiopia

[8] United States Agency for International Development (USAID), (2015). Climate Variability and Change in Ethiopia Summary of Findings; Technical Report; Washington, Dc 20006

[9] FAO, 2013. FAO STAT Database on Agriculture; Food and Agriculture Organization of United Nations; http://faostat3.fao.org

[10] IPCC Fourth Assessment Report (AR4) (2007) Climate Change 2007: Synthesis Report http://www.ipcc.ch/publications_and_data/publications_ipcc_fourth_assessment_report.h tm

[11] Conway D, and Schipper ELF, (2011). Adaptation to climate change in Africa: Challenges and opportunities identified from Ethiopia. Global Environmental Change; Journal homepage: www.elsevier.com/locate/gloenvcha

[12] Climate-Resilient Green Economy (CRGE), 2011. Green economy strategy of Ethiopia; Ethiopia's Climate-Resilient Green Economy Addis Ababa, Ethiopia. Federal Democratic Republic of Ethiopia

[13] USAID, 2012. Climate Change Adaptation in Ethiopia: Fact Sheet Internal resource. 
[14] Ahmed M. Hussen, 2004. Principles of Environmental Economics: Economics, ecology and public Policy, Second edition.

[15] Yalew, Amsalu W.; Hirte, Georg; Lotze-Campen, Hermann; Tscharaktschiew, Stefan (2017). Economic effects of climate change in developing countries: Economy-wide and regional analysis for Ethiopia, CEPIE Working Paper, No. 10/17, Technische Universität Dresden, Center of Public and International Economics (CEPIE), Dresden http://nbnresolving.de/urn:nbn:de:bsz:14-qucosa-227554

[16] Temesgen Tadesse, (2007). Measuring the Economic Impact of Climate Change on Ethiopian Agriculture: Ricardian Approach; Policy Research Working Paper 4342

[17]Zenebe Gebreegziabher, Jesper Stage, Alemu Mekonnen, and Atlaw Alemu, (2011). Climate Change and the Ethiopian Economy: A Computable General Equilibrium Analysis: Environment for Development: Discussion Paper Series, EfD DP 11-09

[18] Di Falco S., Yesuf M. , Kohlin G. and Ringler C., (2011). Estimating the Impact of Climate Change on Agriculture in Low-Income Countries: Household Level Evidence from the Nile Basin, Ethiopia; Springer Science Business Media B.V. 2011 ; Environ Resource Econ DOI 10.1007/s 10640-011-9538-y

[19]Berisso M. ,(2016). Impact of Weather Variations on Cereal Productivity and Influence of Agro-Ecological Differences in Ethiopian Crop Production; Addis Ababa University, Ethiopia

[20] Arega S. and Molla A., (2018). Effect of climate variability on crop income and indigenous adaptation strategies of households, International Journal of Climate Change Strategies and Management, Vol. 10 Issue: 4, pp.580-595, https://doi.org/10.1108/IJCCSM-04-2016-0039

[21] Mideksa Torben K., (2009). Economic and distributional impacts of climate change: The case of Ethiopia; Global Environmental Change; journal homepage: www.elsevier.com/locate/gloenvcha

[22] Paul Evangelista, Nicholas Young and Jonathan Burnett, (2013). How will climate change spatially affect agriculture production in Ethiopia? Case studies of important cereal crops; Springer Science+ Business Media Dordrecht; Climatic Change 119:855-873 DOI 10.1007/s10584-013-0776-6

[23] Seid Nuru, (2012). Climate Change and Economic Growth in a Rain-fed Economy: How Much Does Rainfall Variability Cost Ethiopia? Ethiopian Economics Association

[24] Gujarati, (2004). Basic Econometrics New York, Fourth Edition, Macgraw-Hill Companies.

[25] Wooldridge, J.M., (2003). Introductory Econometrics: A Modern Approach, International Edition.

[26] Harris R.I.D (1995), Using Co-integration Analysis in Econometric Modeling prentice Hall/Harvester Wheatsh, University of Portsmouth

[27] Ogbuabor Jonathan E. and Egwuchukwu Emmanuel I.,( 2017). The Impact of Climate Change on the Nigerian Economy; International Journal of Energy Economics and Policy; ISSN: 2146-4553 available at http: www.econjournals.com

[28]EDRI (2010) Preliminary assessment by the EDRI of impacts, cost and feasibility of strategy Options Climate Resilient Green Growth initiative

[29] Birhan G.,(2017). Impacts of Climate Change on Crop Yields in South Gonder Zone,m Ethiopia: World Journal of Agricultural Research, 2017, Vol. 5, No. 2, 102-110 
[30] Delince J. Ciaian. P. and Witzke Heinz-Peter, (2015). Economic impacts of climate change on agriculture: the AgMIP approach; Journal of Applied Remote Sensing 0970991 Vol. 9, 2015,

[31]CIAT; BFS/USAID. (2017). Climate-Smart Agriculture in Ethiopia. CSA Country Profiles for Africa Series. International Center for Tropical Agriculture (CIAT); Bureau for Food Security, United States Agency for International Development (BFS/USAID), Washington, D.C. 26 p.

[32]Nardone, A., Ronchi, B., Lacetera, N., Ranieri,M., and Bernabucci, U.,(2010). Effects of Climate Changes on Animal Production and Sustainability of Livestock Systems. Livestock Science, 130:57-69.

[33]Rust J.M. \& Rust T., (2013). Climate change and livestock production: A review with emphasis on Africa; South African Journal of Animal Science 2013, 43 (No. 3)

[34]Central Statistical Agency (CSA).(2018). Agricultural Sample Surveys 2017/18: analytical report. The Federal Democratic Republic of Ethiopia; Ethiopia Central Statistics Agency (CSA), Addis Ababa 